Жарких В. Ю.

\title{
ЕВОЛЮЦІЯ КЛІПОВОЇ СВІДОМОСТІ 3 ПОГЛЯДУ ФІЛОСОФІї ПРАГМАТИЗМУ
}

\begin{abstract}
Статтю присвячено еволючиї «кліпової свідомості», новому явищу в суспільній свідомості сучасного суспільства.

Ключові слова: кліпова свідомість, Інтернет, ідентичність, здатність аналізувати інформацію, сочіальні контакти.

The article deals with the evolution of «clip consciousness» - a new phenomenon in the consciousness of present-day society.

Keywords: clip consciousness, internet, identity, ability to analyze information, social contacts.

Статья посвящена эволющчи «клипового сознания», новому явлению в общественном сознании современного общества.
\end{abstract}

Ключевые слова: клиповое сознание, Интернет, идентичность, способность анализировать информацию, социальные контактыл.

Постановка проблеми. У філософії прагматизму поняття «еволюція» розглядають у світлі взаємин організму з довкіллям. Кожен компонент цієї дихотомії, 3 одного боку, випробовує, а з другого - чинить вплив на якість і змістове наповнення цього процесу. Розум людини, будучи дієвою частиною такої взаємодії, не існує окремо від неї. Людська здатність мислити й пізнавати дозволяє виявити та визначити явища й події у всій відмінності і схожості їх різноманітності. Завдяки цій здатності людина визначає їх сенс, якість і цінність у реаліях свого життєвого досвіду.

У цьому контексті відмінні риси людини - свідомість, розум,уява, мова й уся система застосування знаків - сприймаються як ознаки природного процесу адаптації. Вони служать інструментами / способами взаємодії з реальністю, що допомагають людині знайти себе в навколишньому світі [7, с. 51]. Активність людського розуму, жвавість думки людини в пізнанні світу й адаптації у всіх іiі життєвих контекстах становить актуально спрямований, практичний взаємообмін, а не відвернуту, ілюзорну діяльність у пошуках ефемерних ідеалів [7, с. 183]. Як правило, ця діяльність орієнтована на виявлення/конструювання нових реалій, що обіцяють поліпшення умов існування в майбутньому. Вона вибіркова й спрямована на пошук того, що відповідає цілям людини, іiі відчуттям, емоціям і настрою [5, с. 65]. У ній здійснюються дії, викликані певними окремими стимулами, але залишаються непоміченими багато інших. Здатність людини орієнтуватися й складати адекватні висновки в умовах свого життєвого досвіду $є$ біологічною потребою й соціальною необхідністю [7, с. 195]. Практичні потреби пов'язані з викликами й змінами в процесі виживання в змінних реаліях буття. Вони реалізуються в безперервному й неминучому конфлікті / взаємодії між ними й людським організмом / розумом Їх 
наслідки сприяють виникненню нових, якісно відмінних характеристик свідомості й відповідних до них способів мислення. Таким чином людина будує свою реальність, еволюція якої безперервно дає імпульс для розвитку й виживання всього сущого на Землі. У цьому загальному філософському контексті постараємося проаналізувати еволюцію й особливості кліпової свідомості - явища, характерного для реальності XIX ст.

Методологія. Для розв'язання цього завдання звернімося перш за все до роздумів про виникнення якісно нових характеристик свідомості, поданих у працях таких класиків філософії прагматизму, як У. Джеймс, Ф. К. С. Шиллер, а також до робіт А. Тоффлера, С. Теркля, Б. Фогга, Л. Розена, Н.В. Азаренка. Під час викладу основної проблематики статті ми постараємося пов'язати їхні роздуми й доводи 3 проблемою кліпової свідомості, філософське значення якої становить великий інтерес у контексті сьогодення.

Загальна тональність їх досліджень зводиться до пошуку відповіді на питання, чи є феномен трансформації свідомості скороминущим явищем в інтелектуальному житті сучасного суспільства або ж він стає визначальною даністю XIX ст. й у такому разі з яким знаком - позитивним чи негативним - він уписується в реалії наших днів. У статті ми спираємося не тільки на судження й думки класиків прагматизму й сучасних філософів, але й на універсальні дослідницькі методи, широко вживані в наукових дослідженнях.

Виклад основного матеріалу. У людській реальності різного напруження конфронтації й конфлікти $є$ превалювальним тонусом взаємин. Вони є рушійною силою, що мотивує людину на пошук раніше невідомої інформації, нових способів пізнання світу. Із розвитком комунікаційної технології в сучасній реальності незмірно виріс об’єм інформації, зміст і потенціал якої перетворили модель сприйняття світу. Унаслідок цього відбулися драматичні трансформації в людській свідомості, модусах мислення й методах пізнання. Не менш глибокі зміни спостерігаються в структурі інформаційного поля світового комунікативного й соціального простору. Технологічні інновації й різноманітність способів їхнього застосування змінили не тільки політичні й соціальні реальності. Вони докорінно поміняли об'єм і форму обміну інформацією. Разом із безпосередньою, прямою - face-to-face - комунікацією необхідним і важливим елементом людських взаємин стали технологічні засоби зв’язку. Особлива роль у цьому процесі належить Інтернету.

Інтернет значно збільшив число джерел інформації й розширив можливості комунікативних контактів. Він почав повсюдно використовуватися як найбільш зручний спосіб легко й швидко отримувати необхідний об'єм інформації. Не менше значення Інтернет має як інструмент пошуку різноманітних контактів для міжособового спілкування. Він кардинально модифікував характер комунікативної інтеракції. Колишні прямі міжособові форми спілкування стають менш привабливими порівняно з електронними контактами. А це, своєю чергою, трансформує характер соціальних відносин. За допомогою Інтернету легко встановити комунікативний контакт, але значно важче, ніж у прямому, безпосередньому спілкуванні, налагодити стійкі комунікативні стосунки, діалогові й кроскультурні тим більше. Пов’язано це не 
тільки 3 вербальними / невербальними культурними невідповідностями. Інтернет змінює свідомість людини, модифікуючи модель сприйняття реальності. Через це деформується сам принцип людських взаємин і світовідчування. Не менш глибокий вплив Інтернету позначається й на процесі інтерпретації й розуміння інформації.

Сучасна реальність є безперервним процесом комунікації. Вона формується в постійному русі й переплетенні різних відносин, які мають безліч потенційних інтерпретацій. Адекватність і гнучкість у розумінні їх смислу, контекстуального значення й взаємозв' язку багато в чому визначають ступінь і якість адаптації в умовах надлишку інформації й різноманітності людських очікувань. Успішність у реаліях сучасного життя не може бути зведена до однієї інтерпретації, що відображає очікування конкретної людини. У світі постійно змінних зв'язків людина вимушена активно конструювати умови для позитивної соціалізації в контексті множинності різних за характером сенсу тлумачень фактів і обставин. Людині потрібно чуйно й послідовно, цілеспрямовано й гнучко мислити, щоб розуміти значущість, взаємопов'язаність і здійсненність виниклих альтернатив. Бачити тільки одну єдину альтернативу / єдиний погляд не тільки непродуктивно, але й небезпечно. Ступінь успішності здійснення очікувань прямо співвідноситься 3 умінням адекватно оцінювати інформацію й ухвалювати обгрунтовані рішення. Таке уміння припускає здатність неупереджено зіставляти свою позицію з інтересами й цілями інших людей у процесі живого комунікативного обміну. Серед інших важливих якостей для цього необхідна «тривалість уваги» [1, с. 110], завдяки якій правильність і об'єм отриманої інформації не поділяється, а об'єднується в одне ціле.

Сучасна людина живе в інформаційному світі, у якому повідомлення подаються як набір тез без чіткого визначення контексту. Вони орієнтовані на моментальне сприйняття й миттєву реакцію, у яких лінійна послідовність знаків перестає бути базою культури [8, с. 127]. Історично людський життєвий досвід будується в контексті тісного взаємовпливу потоку інформації, що належить як до сьогодення, так і до минулого стану буття. Він грунтується на послідовному мисленні, у процесі якого усвідомлення значущості будь-якої інформації визначається й оцінюється за зв'язками, взаєминами й наслідками поданих у ній повідомлень. У миготінні смислових відрізків у сучасному інформаційному полі людина не в змозі усвідомити зв'язки між фрагментами рознесених у часі подій. Усупереч здоровому глузду в низці окремих фактів іiі свідомість не фіксує їх континуальний зміст. Увага, орієнтована на миттєву реакцію, не фокусується на сприйнятті їх взаємного зв’язку й значущості. В інформаційному полі подана безперервна зміна повідомлень, що весь час вимагає перемикання уваги. Через це все побачене й почуте без тимчасового розриву миттєво застаріває й утрачає своє значення. У свідомості не фіксуються причинно-наслідкові зв'язки, через що мислення стає поверховим. Думка ковзає від одного повідомлення до іншого, не встигаючи стежити за сенсом мерехтливих інформаційних відрізків.

У філософії це явище відоме під терміном «кліпова свідомість (мислення)», який визначає особливість людини сприймати світ за допомогою короткого, яскравого посилу у формі відеокліпу або теленовини [1, с. 110]. Люди 3 кліповою свідомістю втрачають здатність зосередитися. Їхня увага розсівається, вони не можуть 
концентруватися й осмислити зв'язок у постійно змінному потоці миттєвих кадрів.

Сильний бік кліпової свідомості полягає в тому, що вона володіє «швидкісним відгуком» [9, с. 190] і швидко реагує на будь-які стимули й зміни. Люди кліпової свідомості також характеризуються збільшеною здібністю до багатозадачності [6, c. 112]. Вони можуть одночасно займатися різними справами й краще орієнтуватися в інформаційному потоці. Зворотній бік цієї важливої в сьогоднішньому житті якості виявляється в тому, що створюється дефіцит уваги. Через це повідомлення не диференціюються й не осмислюються адекватно й глибоко. Людина не встигає зосередитися на одній інформації, прагнучи встигнути не пропустити наступну. Здібність до аналізу знижується, оскільки світ сприймається роздільно, не як взаємопов'язана цілісність, а як послідовність не пов'язаних між собою подій i фактів.

Розвиток дефіциту уваги спостерігається не тільки в процесі користування Інтернетом, але й у традиційних галузях звичайного життя. Віддаючи перевагу візуальним символам над логікою й поглибленням у текст, людина перестає читати серйозну літературу. Вона насилу стежить за чужою думкою й не завжди ясно розуміє сенс прочитаного, i тим менше вона здатна зв'язно/детально переказати зміст прочитаного. У сферу іiі уваги входять джерела, що допомагають не стати аутсайдером в широкому соціальному контексті. Отримана інформація не аналізується й не зіставляється. Вона існує як набір повідомлень, необхідних для того, щоб «бути в курсі» сьогодні, але не пригадати завтра.

Свідомість, орієнтована на сьогохвилинне сприйняття й миттєву реакцію, не завжди в змозі складати цілісне уявлення про навколишній світ [6, с. 121]. Окремі фрагменти інформації не складаються в загальну картину як якась взаємопов'язана цілісність. У такому роз'єднаному інтелектуальному середовищі швидкої зміни тимчасових образів людина мислить дискретними, уривчастими конструкціями, фактами й моделями. Ї̈̈ мислення стає таким, що ковзає, а уявлення про взаємозалежність і взаємозумовленість світу втрачає системність і впорядкованість. Зміни у свідомості відбиваються й на етиці соціальних відносин. Традиційні уявлення про дружбу, співчуття, щирість і взаємодію стають ідеальними, абстрактними поняттями, що не мають реального втілення в безпосередньому життєвому досвіді.

Не усвідомлюючи реальних взаємозалежностей між явищами й відносинами, некритично сприймаючи їх як набір окремих фактів, людина кліпової свідомості не в змозі адекватно оцінити інформацію, що безперервно надходить. Вона схоплює уривчасті повідомлення поспіхом, нальоту, не виділяючи часу на осмислення й не вміючи читати «між рядків». Вона стикається 3 труднощами в ухвалюванні самостійного рішення й стає податливою до впливів і маніпуляцій. Провести межу між істинною / помилковою інформацією, фактом / вигадкою в інтернет-повідомленні часто не видається можливим [6, с. 98]. Унаслідок цього ухвалення самостійного рішення стає проблематичним і людина легко піддається зовнішньому впливу й навіюванню.

Це відкриває широкі можливості для маніпулювання особистою / колективною свідомістю. В онлайн-комунікації багато повідомлень / месиджів приходять анонімно 
й без дозволу або запрошення. Ідентифікувати їх авторів часто буває майже неможливо. Навіть якщо автор залишає своє ім'я, важко бути впевненим, що воно дійсно відповідає конкретній людині, що послала повідомлення [9, с. 73]. Не утрудняючи себе аналізом отриманих повідомлень або хоч би перевіркою їх правдивості й щирості, людина кліпової свідомості беззастережно вірить у їх істинність і нерідко потрапляє в неприємну / трагічну ситуацію.

У процесі онлайн-комунікації 3 людиною відбуваються незворотні зміни. Кліпова свідомість, яка виникає в неї, впливає на якість комунікативних зв'язків, порушуючи традиційний формат спілкування. Комп'ютер стає надійним співрозмовником / другом / радником, 3 успіхом замінюючи безпосереднє спілкування віч-на-віч. Спілкування в Інтернеті стає набагато комфортнішим. Здатність побудувати позитивно значущу атмосферу інтерактивного спілкування, не кажучи вже про живий діалог, щоб сприймати й обговорювати серйозні / несерйозні проблеми, знижується. Передати повідомлення Інтернетом стає швидшим, спокійнішим і якоюсь мірою етично безпечнішим. В електронних мережах не існує традиційних умовностей, що визначають модус поведінки. У реальному живому досвіді дійсно складні соціальні й політичні дискусії, як і міжособові інтеракції, нерідко перетворюються на публічні сварки, що викликає негативну реакцію в суспільстві. В Інтернеті люди дають вихід особистим образам на своїх співбесідників. Вони не обмежуються у виразах. Приниження / образа опонента визнається найбільш адекватним аргументом. Спілкування в електронних мережах звільняє людину від відповідальності бути щирою, поважною й увічливою. У таких комунікативних подіях ніхто не слухає й не чує нікого, окрім себе самого. Соціально / інтелектуально / морально значущі відмінності безпідставно спотворюються й навмисно перебільшуються / применшуються. Замість глибокого обговорення ідей і думок електронний дискурс стає розважальним заходом, що ні до чого не зобов'язує. Він є спілкуванням без змісту й сенсу, без конструктивних наслідків і позитивного майбутнього.

Кліпова свідомість вторгається в життя на екрані й міняє світогляд. Її вплив примушує людей переоцінювати свою самосвідомість [9, с. 131]. Ставлення до себе, до інших і до реальності змінюється, оскільки люди втрачають цілісність самосприйняття. Вступаючи в діалог із комп'ютером, вони створюють нереальні світи й віртуальні ідентичності. Процес формування культурної й особової ідентичності в Інтернеті $\epsilon$ свого роду грою в складання казкових сюжетів, вигадуванням віртуальних образів і обставин [4, с. 219]. Обидві сторони онлайнкомунікації говорять притчами, тому що «бачивши не бачать, і чувши не чують, i не розуміють» [2.13:13;15]. У цій грі відбувається довільне змішення / переплетення дійсних i фіктивних якостей множинних реальних/ірреальних ідентичностей. Завдяки цьому створюються неперевершені умови для маніпулювання, містифікації й обману. Надумані привабливі образи, співзвучні цій конкретній ситуації, у реальному житті опиняються порожньою фантазією. Кліпова свідомість з легкістю переносить їх 3 одного образу в іншій, незалежно від наслідків такого перетворення.

У контексті кліпової свідомості створюються нові контекстуальні ідентичності 
через віртуальну інтеракцію. Люди не в змозі створити змістовні відносини, засновані на рівноправних взаєминах, у якому визнаються/виражаються дійсні відчуття дружби, прихильності й пошани. Вони прагнуть задовольнити свою потребу в розширенні й зміцненні в новому віртуальному просторі своїх комунікативних зв'язків, не існуючих/не здійснюваних у їх реальних соціальних і культурних контекстах. Учасники онлайн-контакту стають авторами не тільки текстового повідомлення / обміну. Вони створюють свою нову ідентичність, грунтуючись на переплетенні істинного й онлайн-уявлення про себе, із тим щоб установити найбільш оптимальний для цієї інтернет-ситуації віртуальний контакт. Це недовговічний образ. Відповідно до кліпової свідомості він змінюється й обростає новими характеристиками залежно від обставин контексту інтеракції. У Інтернеті люди використовують слова й ситуації, щоб грати ролі вигаданих персонажів у таких же вигаданих світах [8, с. 11], не надаючи значення наслідкам і взагалі не думаючи про них. Межа між реальною особою й грою, дійсністю й фантазією, імітацією й істиною затуманюється, і людина забуває про те, що вона $\epsilon$ насправді. Ії̈ віртуальні комунікатори сприймають іiі в тому образі, який вона собі придумала. Через це у випадку, якщо відбувається особистий комунікативний контакт у реальних умовах, виникають труднощі пізнавання, нерозуміння й розчарування.

Створюється враження, що ситуація стає незворотною. Проте слід пам'ятати, що феномен «кліпової свідомості» $є$ фактом сучасного світу. Це - нове явище, незрозуміле й незвичне. Якоюсь мірою воно здається небезпечним у контексті століттями визнаних понять. Це настільки нове поняття, що навіть термін, що його визначає, не має однозначного вираження: термін «кліпова свідомість» існує разом 3 «кліповим мисленням» і ширшим поняттям «кліпова культура». Не існує й адекватно аргументованого визначення цього феномена. Але, як відомо, усяка новина чи нововведення спочатку викликає неприйняття й лише в процесі життєвої практики знаходить свою реальну значущість і визнану цінність у суспільній свідомості.

Висновки. Розглянувши проблему кліпової свідомості, можемо зробити висновок, що в інтелектуальному просторі сучасного суспільства відбуваються значні, очевидно, незворотні зміни. Цей процес віддзеркалює безпосередні інтереси й потреби реальності цього історичного часу. У концепціях прагматизму визнано, що пластична, недосконала, змінна реальність створюється людиною. Ця реальність завжди прагматична. Вона є те, що людина вважає важливим, потрібним та істотним. У сучасній реальності розвиток нових технологічно оснащених засобів комунікації призвів до виникнення потреби міняти як практику отримання / пошуку інформації, так і трансформував модус людського спілкування. Унаслідок цих змін для того, щоб вижити й досягти успіху, людина вимушена адаптуватися як інтелектуально, так фізично й морально до того, щоб сприймати дійсність у реаліях кліпової свідомості. Поки що оцінка позитивних / негативних ознак кліпової свідомості не має однозначного тлумачення. Подальше вивчення кліпової свідомості допоможе адекватно визначити цінність цього феномена. Заснований на принципі «розумної рівноваги», філософський аналіз дозволить знайти спосіб скористатися перевагами й нівелювати негативні якості цього неоднозначного явища. 


\section{Література:}

1. Азаренок Н. В. Клиповое сознание и его влияние на психологию человека в современном мире // Мат-лы Всероссийской юбилейной научной конференции, посвященной 120-тилетию со дня рождения С. Л. Рубинштейна. Т.5. М. Изд-во Ин-та психологии РАН, 2005. С. 110-112.

2. Библия. Книги Священного Писания Старого и Нового Завета. М. : Из-во Библейского общества,Т.2 : Новый Завет, 1994. 292 с.

3. Жарких В. Ю. Побудова реальності: метафізика еволюції у філософії Ф. К. С. Шиллера // Мультиверсум. Філософський альманах. Київ : Український Центр духовної культури, 2007. Вип. 60. C. $105-116$.

4. James W. Pragmatism. Harvard UP, 1907. 186 p.

5. Fogg B. J. Persuasive Technology: Using Computers to Change What We Think and What We Do. Elsevier Science Pub., 2002. 312 p.

6. Rosen L. Me, My Space, and I: Parenting the Net Generation. N-Y., Free Press, 2007. 258 p.

7. Schiller F. K. S. Logic for Use. N-Y.; Harcourt, Brace and Co., 1930. 469 p.

8. Toffler A. Future Shock. Bantam,1984. 576 p.

9. Turkle S. The Second Self: Computer and the Human Spirit. The MIT P, 2005. 386 p.

\section{Volodymyr Zharkykh}

\section{An EVOLUTION OF CLIP CONSCIOUSNESS IS FROM POINT OF VIEW PHILOSOPHY OF PRAGMATISM}

In classical pragmatism, evolution is understood in light of interrelation of an organism and its environment. The thinking and knowing ability of man is no exception. The purely human features - consciousness, reason, imagination, language and the use of signs - are treated as realization of the natural process of adaptation.

Pragmatism maintains that reason does not exist separately from environment. Man uses his reason to better adapt and accommodate in human/nonhuman contexts. This ability is a biological need and necessity in his struggle for survival. In the constantly changing world, challenges, that man faces in his everyday experience, stimulate the appearance of new ways of perceiving the world and thinking of its transformations.

Present-day technological innovations have transformed political and social relations in the global world. Among other things, Internet is of utmost importance for changes in face-to-face social contacts. In this respect it is responsible for alterations in man's consciousness and his way of thinking. It led to modification and deformation of the very principle of human worldview and social interrelation.

In philosophy this phenomenon is known as «clip consciousness / thinking». It is roughly explained as a peculiar ability to simultaneously perceive the world through short, often unrelated messages in the form of video clips or TV news.

Internet affected the volume and form of information exchange and dissemination because the structure of the information space had become different. It is filled with an unstoppable stream of messages which human mind cannot sensibly grasp. As a result 
attention becomes unfocused, shallow and imperceptive. On the other hand, people with clip consciousness are able to simultaneously perceive various information and do different things.

The notion «clip consciousness» has not yet been adequately defined and appreciated. It requires further analysis and evaluation on the principle of reasonable balance.

Keywords: clip consciousness, internet, identity, ability to analyze information, social contacts.

\section{Володимир Жарких}

\section{ЕВОЛЮЦІЯ КЛІПОВОЇ СВІДОМОСТІ 3 ПОГЛЯДУ ФІЛОСОФІЇ ПРАГМАТИЗМУ}

У класичному прагматизмі поняття «еволюція» розуміють у світлі взаємин організму з довкіллям. Здатність людини думати й пізнавати не $\epsilon$ винятком. Відмінні риси людини - свідомість, розум, уява, мова, уся система застосування знаків сприймаються як ознаки природного процесу адаптації.

Прагматизм стверджує, що розум не існує відірвано від навколишнього середовища. Людина використовує свій розум для того, щоб краще адаптуватися в людських / нелюдських контекстах. Ця здатність $\epsilon$ біологічною потребою й необхідністю в іiі боротьбі за виживання. У мінливому світі виклики, які людина зустрічає у своєму життєвому досвіді щодня, стимулюють появу нових способів усвідомлення світу й нових методів осмислення його трансформацій.

Сучасні технологічні новації трансформували політичні й соціальні відносини в глобальному світі. Середі інших речей Інтернет не тільки зіграв значну роль у змінах у соціальних контактах віч-на-віч. Завдяки його впливу відбулися зміни в людській свідомості й модусах мислення. Це призвело до модифікації самого принципу людського світосприйняття й соціальних взаємин.

У філософії цей феномен відомий як «кліпова свідомість / мислення». У приблизному тлумаченні це особлива здатність людини сприймати й усвідомлювати світ шляхом коротких, часто не пов'язаних між собою месиджів у формі відеокліпів або ТВ-новин.

Вплив Інтернету відчувається в зміні об'єму й форми обміну та розповсюдження інформації, тому що сама структура інформаційного простору стала іншою. Вона заповнена безперервним потоком месиджів, який людський розум не в змозі адекватно й послідовно сприйняти. У результаті увага стає несфокусованою, неглибокою й несприйнятливою. 3 другого боку, люди кліпової свідомості здатні одночасно сприймати різну інформацію й робити кілька різних справ.

Поняття «кліпова свідомість» ще не має адекватного визначення. Воно потребує аналізу й оцінки в контексті принципу розумної рівноваги.

Ключові слова: кліпова свідомість, Інтернет, ідентичність, здатність 
аналізувати інформацію, сочіальні контакти.

Zharkykh Volodymyr, Professor, Doctor of Philosophy Sciences Odessa National Polytechnic University.

Жарких Володимир Юрійович - доктор філософських наук, професор, завідувач кафедри філософії та методології науки гуманітарного факультету Одеського національного політехнічного університету.

e-mail: vzharkykh@gmail.com

ORCID: 0000-0003-2829-9625

Надійшла до редакції 30.06.2018. Розглянута на редколегії 17.09.2018.

\section{Рецензенти:}

Доктор філософських наук, доцент, професор кафедри філософії Національного аерокосмічного університету ім. М.С. Жуковського «ХАІ» Кузнецов А.Ю.

Доктор філософських наук, професор, професор кафедри філософії Харківського національного університету Повітряних Сил імені Івана Кожедуба Панфілов О.Ю. 